\title{
A quarter of a century of the Birmingham Eye Trauma Terminology (BETT) system
}

\author{
Ferenc Kuhn ${ }^{1,2,3} \cdot$ Robert Morris $^{1}$
}

Received: 15 August 2021 / Revised: 15 August 2021 / Accepted: 30 August 2021 / Published online: 6 September 2021

(c) The Author(s), under exclusive licence to Springer-Verlag GmbH Germany, part of Springer Nature 2021

\section{Key messages}

- The impact of establishing a standardized language for eye-injury description is illustrated.

- BETT has eliminated the confusion in ocular-trauma terminology.

In the early 1990s, one of the authors (FK) moved from Hungary to the USA. Before, he had for several years worked as an on-call trauma surgeon: if the resident ophthalmologist at the Level-1 emergency center needed support, he would be called to provide it over the phone or on-site. Any time a patient arrived with an open-globe trauma, the resident described the case as a "perforating injury."

The question of what the definition of a "perforating injury" was never came up. It was after crossing the Atlantic that the author realized: the very same injury that most ophthalmologists in Europe described as "perforating" was considered as "penetrating" in the America.

The recognition of this controversy leads to a pilot study, conducted at a major trauma center in the USA. Seventeen ophthalmologists filled out a survey containing several detailed case reports with "open globe" trauma. Each ophthalmologist was asked to select for each case from the following clinical diagnoses: "rupture," "penetrating," "perforating," and "intraocular foreign body." For eyes with

Ferenc Kuhn

fkuhn@mindspring.com

1 Helen Keller Foundation for Research and Education, Birmingham, AL, USA

2 International Society of Ocular Trauma, Birmingham, AL, USA

3 Department of Ophthalmology, University of Pécs Medical School, Pécs, Hungary "closed globe" trauma, the selection included "blunt" and "contusion."

Shockingly, no two response sheets were identical-this at a facility with a large volume of trauma cases and in a community of eye surgeons who had worked together for several years.

The survey confirmed that the terms describing eye injury types were not simply inconsistent but confusing. After a thorough literature search, this statement had to, no less shockingly, be upgraded into no ocular trauma terminology system exists. Every practicing-publishing ophthalmologist used terms that were subjective; and when these were communicated to colleagues, their interpretation was just as subjective. The situation was akin to two people discussing an important topic without sharing a common language.

Realizing this, a system had to be established that would be simple (a complicated one has no chance of getting accepted in clinical practice) yet comprehensive (covering every type of mechanical injury). All terms in the system must have a clear definition; furthermore, no term can describe more than a single type of injury and no injury type can be associated with more than one term. Finally, to avoid any misunderstanding, all injury terms must be stand-alone, relating to the entire eyeball, not to a tissue: "corneal penetrating injury" describes an injury with a single (entrance) wound; "corneal" simply indicates that the wound is in the cornea.

This is how the Birmingham Eye Trauma Terminology (BETT) system was born, even if it was not originally named as such. It was published, almost simultaneously, in a major 
European (Graefe's) and American (Ophthalmology) journal, providing a standardized basis for the field of ocular traumatology $[1,2]$. Without such a standard, confusion would still reign in clinical practice, and even basic research studies would be impossible to conduct [3]. The significance of BETT is shown by the fact that it is the second mostreferenced article in the trauma literature [4] with over 420 citations (Researchgate), and that the most-referenced article is also based on it [5]. There are worthy efforts to improve on the BETT system [6,7], but so far none has been incorporated into use.

It is now 25 years ago that BETT was officially introduced; the authors are very grateful to the editors at Graefe's to publish this commemoration at the anniversary.

\section{References}

1. Kuhn F, Morris R, Witherspoon CD, Heimann K, Jeffers J, Treister G (1996) A standardized classification of ocular trauma terminology. Graefe's Arch Clin and Exp Ophthalmol 234:399-403

2. Kuhn F, Morris R, Witherspoon CD, Heimann K, Jeffers J, Treister G (1996) A standardized classification of ocular trauma terminology. Ophthalmology 103:240-243

3. Kuhn F, Maisiak R, Mann L, Mester V, Morris R, Witherspoon CD (2002) The Ocular Trauma Score (OTS). Ophthalmol Clin North America 15:163-166

4. Bulut E, Dokur M, Basar E (2020) The top 100 cited articles on ocular trauma: a bibliometric analysis. Eur J Ther 26(4):322-331

5. Pieramici DJ et al (1997) A system for classifying mechanical injuries of the eye (globe). Am J Ophthalmol 123:820-831

6. Xiao JH, Zhang MN, Li SY, Jiang CH, Jiang H, Zhang Y et al (2014) A new classification for epidemiological study of mechanical eye injuries. Chin J Traumatol 17:35-37

7. Shukla B, Agrawal R, Shukla D, Seen S (2017) Systematic analysis of ocular trauma by a new proposed ocular trauma classification. Ind J Ophthalmol 65:719-722

Publisher's note Springer Nature remains neutral with regard to jurisdictional claims in published maps and institutional affiliations. 